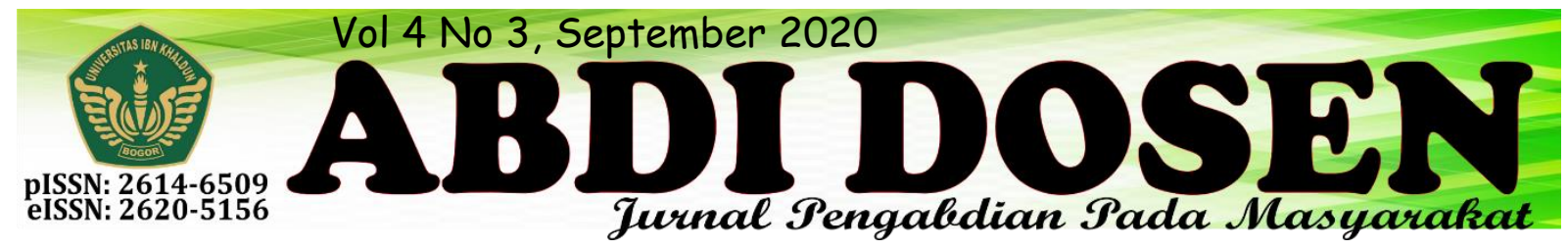

\title{
PENINGKATAN PRODUKTIFITAS UMKM INDUSTRI KREATIF DI ERA MEA DENGAN PEMANFAATAN TEKNOLOGI TEPAT GUNA
}

\author{
Budi Gunawan $^{1}$, Mukhammad Nurkhamid ${ }^{2}$, Sri Mulyani ${ }^{3}$ \\ budi.gunawan@umk.ac.id ${ }^{1}$ \\ muhammad.nurkamid@umk.ac.id ${ }^{2}$ \\ s.mulyani@umk.ac.id \\ ${ }^{1,2}$ Fakultas Teknik, ${ }^{3}$ Fakultas Ekonomi Bisnis \\ Universitas Muria Kudus, Jl. Lingkar Utara UMK, Gondangmanis, Bae, Kudus - 59327 Jawa Tengah
}

\begin{abstract}
ABSTRAK
Di era MEA, Indonesia dan sembilan negara ASEAN lain memiliki kesempatan yang sama untuk memanfaatkan pasar yang terintegrasi dalam satu kawasan. Karena sudah berlaku, tidak ada pilihan lain bagi masyarakat di negara-negara ASEAN, termasuk dunia usaha, baik besar maupun segmen usaha mikro, kecil, dan menengah (UMKM), selain harus siap menghadapi ASEAN open market. Apabila UMKM ditempatkan di pasar secara bebas, kelangsungan hidupnya akan ditentukan oleh pasar, dan dengan berbagai keterbatasan yang dimilikin ya tentu akan kesulitan bersaing dengan pelaku usaha yang menjadi bagian dari jaringan konglomerasi global. Untuk itu diperlukan dukungan dan bantuan dari semua elemen, baik pemerintah maupun kalangan akademisi dalam meningkatkan daya saing UMKM bisa berkembang di arena pasar terbuka ini. Salah satu pelaku UKM yang bergerak dalam industri kreatif adalah UKM "Tyara Craft" yang memanfaatkan bahan limbah yaitu 'bonggol jagung' untuk dirubah menjadi barang kerajinan yang mempunyai nilai ekonomis. UKM ini merupakan UKM yang sedang berkembang dengan tenaga kerja berjumlah 6 org. UKM ini berdiri sejak tahun 2017 dengan total omset per tahun 156 juta. Produk UKM ini adalah barang-barang kerajinan dari bahan bonggol jagung seperti lampu gantung, cincin, meja kursi, pigura, tempat tisu dsb. Tujuan dari kegiatan ini adalah: meningkatkan produktifitas UKM industri kreatif yang memproduksi barang kerajinan dari bahan limbah, yaitu bonggol jagung, dengan memanfaatkan teknologi tepat guna yaitu mesin pengamplas dan pemotong. Metode pelaksanaan dibagi dalam tiga tahap; (1) perancangan dan pembuatan TTG, (2) pelatihan penggunaan TTG, dan (3) workshop peningkatan keahlian tenaga kerja dalam pemanfaatan TTG. Hasil kegiatan ini adalah; (1) peningkatan produktifitas UKM , (2) peningkatan keahlian UKM, (3) peningkatan omset penjualan dengan meningkatnya volume produksi
\end{abstract}

Kata kunci: UMKM, produktifitas, teknologi tepat guna, industri kreatif, kerajinan

\section{PENDAHULUAN}

Saat ini terdapat pergeseran orientasi gelombang ekonomi, dimulai dari perubahan era pertanian ke era industrialisasi, setelah itu terbentuk era informasi yang diikuti dengan penemuan-penemuan bidang teknologi informasi. Pergeseran gelombang ini telah membawa peradaban yang baru dan semakin berkembang. Dampak yang muncul akibat dari fenomena perubahan 
gelombang ini adalah munculnya daya saing atau kompetisi pasar yang semakin besar. Negara-negara maju mulai menyadari bahwa saat ini mereka tidak bisa hanya mengandalkan bidang industri sebagai sumber ekonomi di negaranya tetapi mereka harus lebih mengandalkan sumber daya manusia yang kreatif karena kreativitas manusia itu berasal dari daya pikirnya yang menjadi modal dasar untuk menciptakan inovasi dalam menghadapi daya saing atau kompetisi pasar yang semakin besar. Sehingga pada tahun 1990an dimulailah era ekonomi baru yang mengutamakan informasi dan kreativitas dan populer dengan sebutan Ekonomi Kreatif yang digerakkan oleh sektor industri yang disebut Industri Kreatif (Purnomo, 2019).

Secara khusus pengembangan industri kreatif di Indonesia dituangkan dalam bentuk Instruksi Presiden Republik Indonesia nomor 6 Tahun 2009 tentang Pengembangan Ekonomi Kreatif. Kebijakan ini ditujukan untuk mengembangkan perekonomian rakyat yang bertumpu pada kreativitas, keterampilan, dan bakat individu untuk menciptakan daya kreasi dan daya cipta individu yang bernilai ekonomis dan berpengaruh pada kesejahteraan masyarakat (Ramdani, 2015).

Di Indonesia industri kreatif mulai banyak dilirik oleh banyak kalangan karena sangat menjanjikan untuk jangka waktu yang panjang. Meningkatnya kreativitas dan inovasi baru yang dikembangkan masyarakat Indonesia, ternyata mendorong kemunculan industri kreatif di berbagai penjuru nusantara, bahkan secara sengaja Pemerintah Indonesia mulai mensosialisasikan ekonomi kreatif guna mengurangi angka pengangguran yang cukup besar (Arif, 2009).
Pertumbuhan dan pengembangan potensi industri kreatif di Indonesia tidak terlepas dari kontribusi pemerintah dan para wirausaha yang mengembangkan Usaha Menengah Kecil dan Mikro (UMKM) dibidang industri kreatif yang memiliki kontribusi PDB 59,08\% sebesar 4.869,5 triliun per tahun dan menyerap tenaga kerja 97,16\% atau sebanyak 107.657.509 jiwa. UMKM selalu digambarkan sebagai sektor yang mempunyai peranan penting. Sehingga UMKM memainkan suatu peran vital di dalam pembangunan dan pertumbuhan ekonomi (Repositori USU, 2015)

Sesuai dengan pilar utama MEA, akan tercipta pasar tunggal di wilayah ASEAN. Indonesia sebagai anggota ASEAN yang mempunyai jumlah penduduk paling banyak akan sangat berpotensi menjadi pasar yang kuat untuk perdagangan barang dan jasa yang dihasilkan oleh Negara-negara di ASEAN. Sama halnya dengan akan diberlakukannya Masyarakat Ekonomi ASEAN, hal tersebut juga akan menjadi peluang sekaligus tantangan bagi produk-produk Industri kreatif yang dihasilkan oleh UMKM di Indonesia. sehingga dalam hal ini peningkatan daya saing UMKM menjadi faktor kunci agar mampu menghadapi tantangan dan memanfaatkan peluang dari implementasi MEA,

Salah satu pelaku UKM yang bergerak dalam industri kreatif di daerah Pati dari desa Sarirejo adalah UKM Tyara Craf yang memanfaatkan bahan limbah yaitu 'bonggol jagung' untuk dirubah menjadi barang kerajinan yang mempunyai nilai ekonomis tinggi. UKM ini merupakan UKM yang sedang berkembang dengan tenaga kerja berjumlah 6 orang yang terdiri dari tenaga pengamplas, pemotong, merangkai dan tenaga finishing. UKM ini 
berdiri sejak tahun 2017 dengan total omset per tahun 156 juta. Produk UKM ini adalah barang-barang kerajinan dari bahan bonggol jagung seperti lampu gantung, cincin, meja, kursi, pigura, tempat tisu, plafon, gelang dan pipa rokok. Pemasaran hasil produk dari UKM ini sudah sampai ke beberapa kota besar seperti Jakarta, Bogor, Yogyakarta dan Surakarta. Kedepan dengan program PPPUD ini di orientasikan perluasan pemasaran sampai ke pasar global, sehingga bisa meningkatkan daya saing UKM di era MEA.

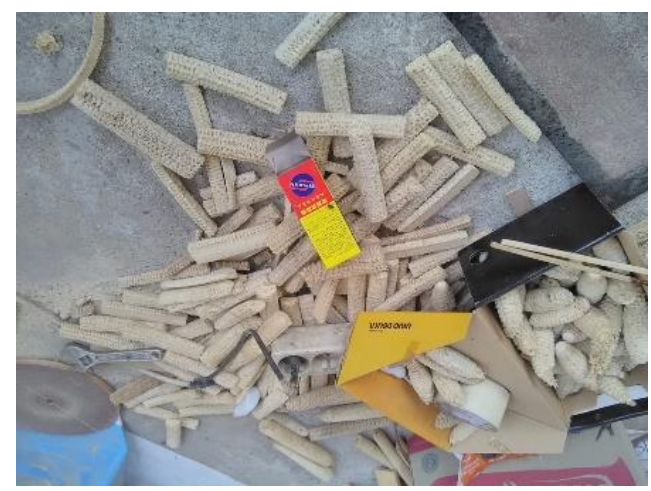

Gambar 1. Bonggol jagung sebagai bahan baku utama UKM mitra "Tyara Craf"
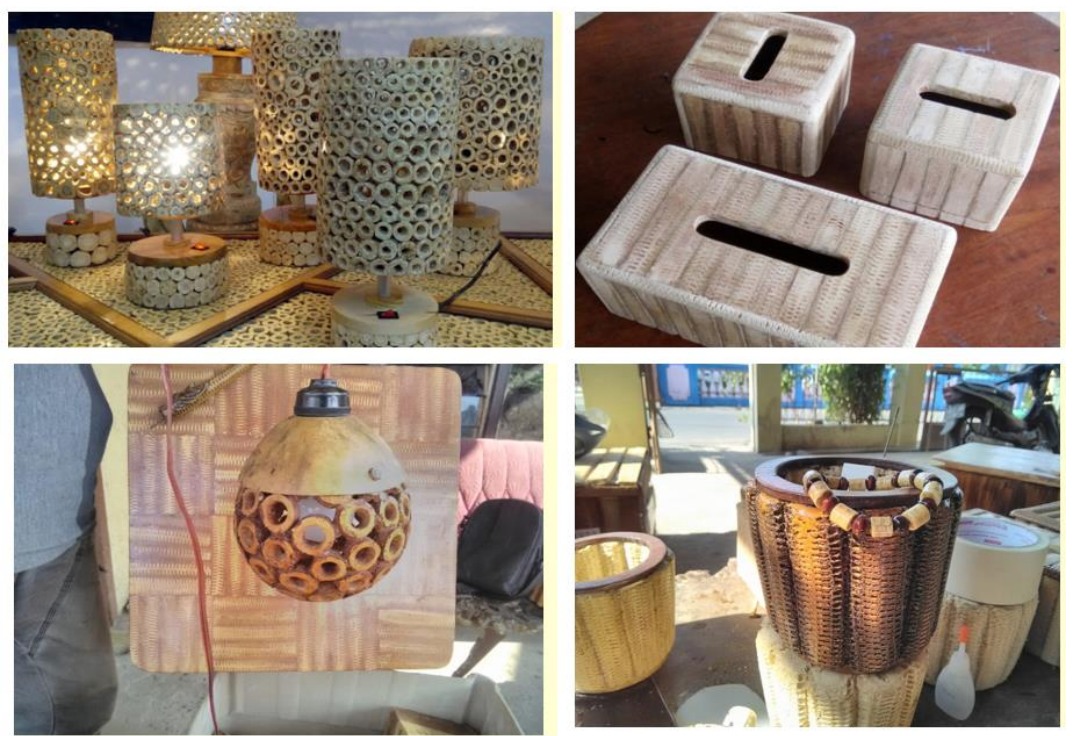

Gambar 2. Produk-produk kerajinan UKM mitra “Tyara Craf” dari bonggol jangung.

Tingginya tingkat persaingan pasar mendorong para pelaku UKM untuk meningkatkan hasil kinerjanya sehingga memiliki nilai tambah dan berdaya saing, baik di pasar nasional maupun pasar global. Dengan kondisi demikian tentu peran teknologi tepat guna dalam memajukan usaha sangat dibutuhkan. Dengan memanfaatkan teknologi tersebut, para pelaku UKM bisa mempercepat proses produksi.
Sesuai dengan Permendagri 20/2010 tentang Pemberdayaan Masyarakat Melalui Pengelolaan Teknologi Tepat Guna, saat ini peranan teknologi memang sangat penting untuk mendongkrak kinerja UKM dan mengatasi kesulitan yang sering mereka hadapi khususnya dalam hal memproduksi barang komoditas yang berkualitas. Melalui sentuhan teknologi dan didukung dengan SDM yang handal, diharapkan kualitas produk yang dihasilkan pelaku UKM bisa 
terjaga kualitasnya, sehingga bisa bersaing dengan produk luar negeri dan untung yang dihasilkan bisa semakin besar.

Tujuan dari kegiatan ini adalah: meningkatkan produktifitas UKM industri

\section{METODE}

\section{a. Tahapan Pelaksanaan}

Metode pelaksanaan dibagi dalam tiga tahap; (1) perancangan dan pembuatan TTG, (2) pelatihan penggunaan TTG, dan (3) workshop peningkatan keahlian tenaga kerja dalam pemanfaatan TTG.

(1) Perancangan dan pembuatan TTG

Pada proses perancangan alat TTG melibatkan pelaku UKM untuk mendapatkan masukan akan sepesifikasi dan fungsi alat yang diharapkan oleh UKM. Desain mesin pengamplas menggunakan dinamo dan piringan amplas serta lubang berdiameter $0,25 \mathrm{~cm}$ x $20 \mathrm{~cm}$ dengan cerobong pembuangan dan tempat pembuangan. Sedangkan mesin pemotong menggunakan bahan utama gergaji, cerobong pengarah hasil potongan dan tempat hasil potongan bonggol jagung.

(2) Pelatihan penggunaan alat TTG

Pada tahap ini dilakukan pelatihan penggunaan TTG dari tim pelaksana pengabdian masyarakat kepada UKM yang terdiri dari pemilik UKM dan tenaga kerjanya. Pelatihan ini dimaksudkan untuk mengenalkan pemanfaatan TTG dalam menunjang produktifitas UKM, dijelaskan proses kerja alat dan penggunaanya.

(3) Workshop peningkatan keahlian tenaga kerja dalam pemanfaatan TTG

Kegiatan workshop ini dimaksudkan untuk meningkatkan keahlian dari UKM dengan mengambil narasumber dari UKM kerajinan sejenis daro Yogya yang berpengalaman sudah memanfaatkan TTG dalam menunjang produksinya. Kegiatan worshop ini dilaksanakan melalui internet kreatif yang memproduksi barang kerajinan dari bahan limbah, yaitu bonggol jagung, dengan memanfaatkan teknologi tepat guna yaitu mesin pengamplas dan pemotong.

dengan webinar karena saat pelaksanaan masih masa pandemi Covid-19. Dari webinar ini, narasumber memberikan arahan sekaligus praktek penggunaan alat TTG supaya bisa menghasilkan produk yang bagus dengan waktu yang lebih efektif.

\section{b. Pemantauan Kegiatan}

a. Pemantauan kemajuan pekerjaan di lapangan:

1. Seluruh kegiatan diusahakan dijalankan sesuai jadwal rencana kerja yang telah dibuat.

2. Tim pelaksana terjun langsung dalam setiap tahap pelaksanaan dengan mempertimbangkan keinginan atau kebutuhan yang diinginkan oleh UMKM.

b. Pemantauan setelah program selesai dilaksanakan:

1. Tim pelaksana datang ke lokasi pengusaha UMKM untuk melihat perkembangan usaha mitra secara periodik setiap minggu sekali selama 1 bulan setelah program berakhir.

2. Komunikasi antara tim pelaksana dan pengusaha UMKM elalu dijaga, agar kemajuan yang dicapai dan permasalahan yang dimungkinkan timbul dapat segera diatasi.

\section{c. Evaluasi}

Evaluasi program dilakukan untuk melihat keberhasilan kegiatan secara keseluruhan. Evaluasi ini dilakukan secara bertahap dan berkala. Secara bertahap akan 
di monitor dan avaluasi keberhasilan UKM menerapkan TTG yang telah dilaksanakan,

\section{HASIL, PEMBAHASAN, DAN DAMPAK}

Kegiatan program pengabdian kepada masyarakat ini melibatkan UKM secara langsung baik dalam proses pelaksanaan maupun dalam sharing pendanaan. Dalam proses desain dan perancangan alat TTG UKM dilibatkan untuk memberi masukan kebutuhan alat yang diharapkan, dalam proses pembuatan alat, UKM dilibatkan dalam try and error alat sbelum jadi, dan pada proses pelatihan UKM terlibat langsung beserta tenaga kerjanya untuk mengikuti kegiatan pelatihan, baik saat pelatihan penggunaan alat TTG maupun saat workshop dengan narasumber dari Yogya. Berikut proses tahapan dan dokumentasi kegiatan;

(1) Perancangan dan pembuatan TTG manfaat bagi UKM dan peningkatan produksi UKM.
TTG yang akan dibuat ada 2 alat; yaitu (1) alat pengamplas, dan (2) alat pemotong bahan. Pada proses perancangan alat TTG melibatkan pelaku UKM untuk mendapatkan masukan akan sepesifikasi dan fungsi alat yang diharapkan oleh UKM. Desain mesin pengamplas menggunakan dinamo dan piringan amplas serta lubang berdiameter $0,25 \mathrm{~cm} \times 20 \mathrm{~cm}$ dengan cerobong pembuangan dan tempat pembuangan. Sedangkan mesin pemotong menggunakan bahan utama gergaji, cerobong pengarah hasil potongan dan tempat hasil potongan bonggol jagung. Gambar desain rancangan dan proses pembuatan di bengkel las diperlihatkan pada gambar dibawah;
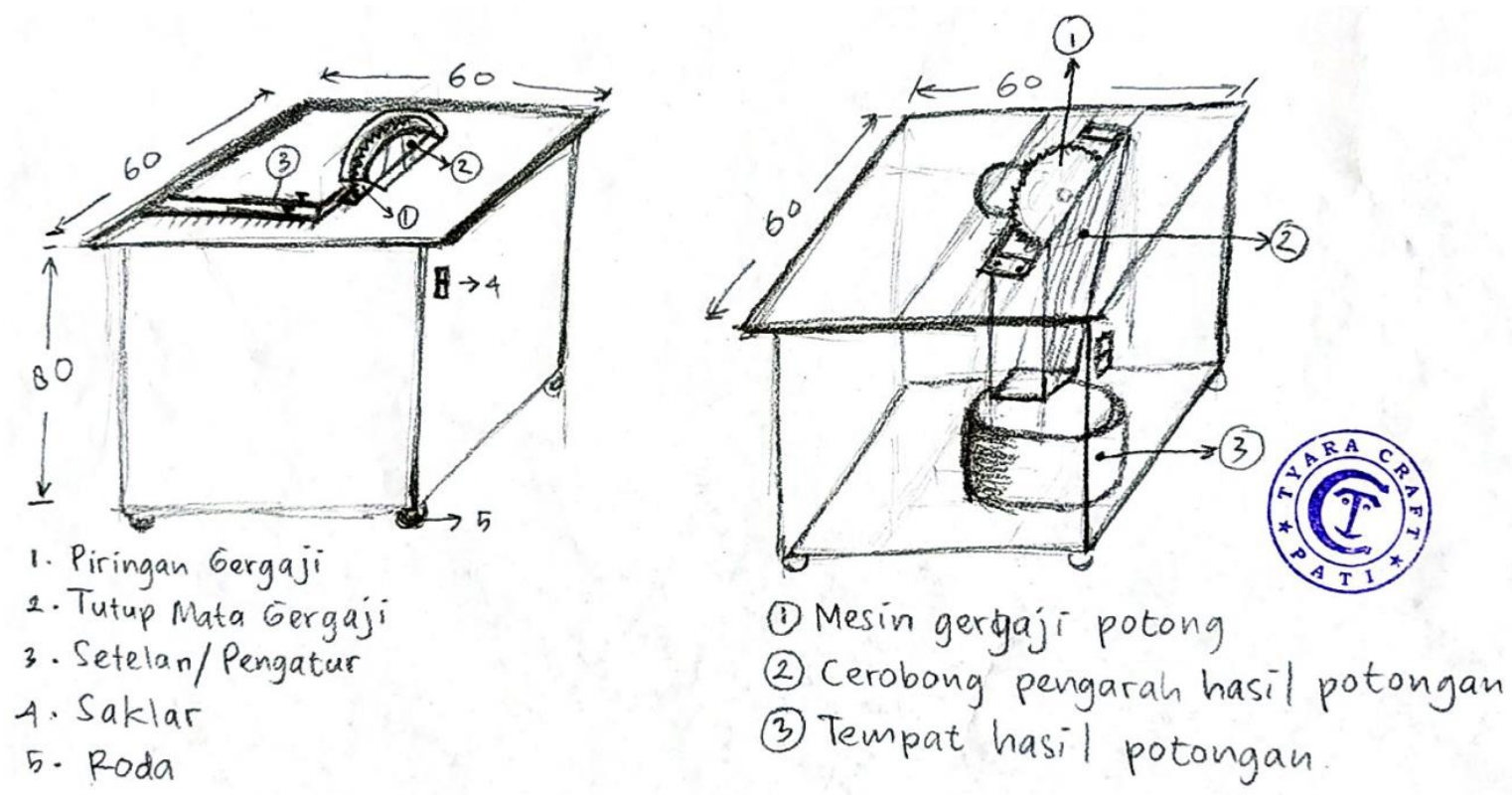

Gambar 3. Rancangan alat pemotong bahan. 


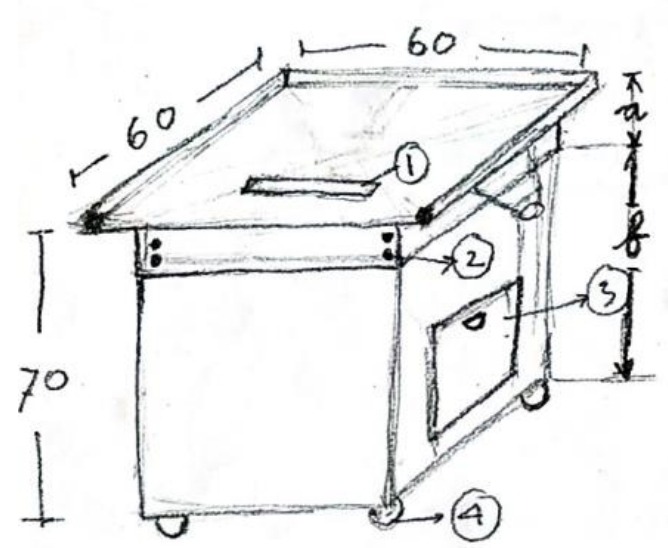

(1) lubang $0.2,5 \mathrm{~cm} \times 20 \mathrm{~cm}$

(2) Setelan tutup.

(3) Pintu

(4) Roda

$a=$ Tutup Meja

$b=$ Meja

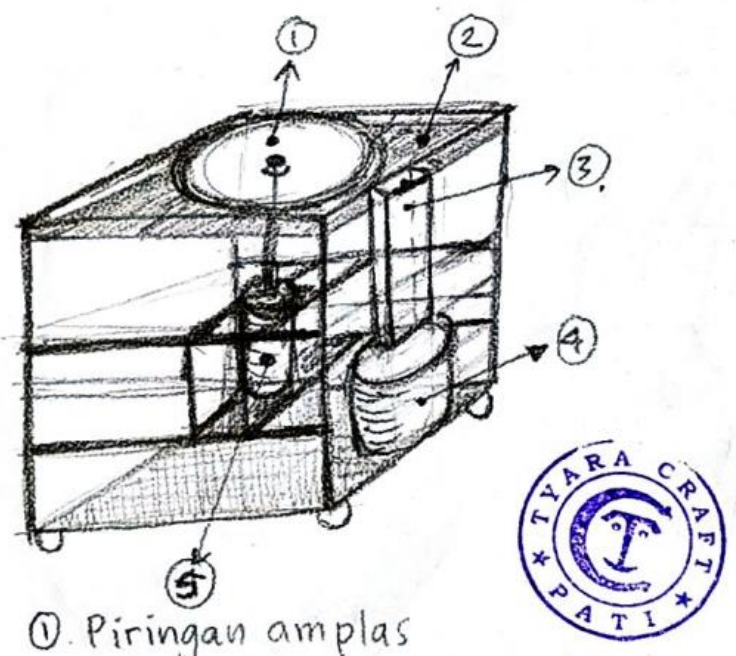

(2) Dasar Meja

(3). Cerobong Pembuangan

(4). Tempat Pembuangan

(5). Dinamo/Mesin

Gambar 4. Rancangan alat pengamplas bahan.
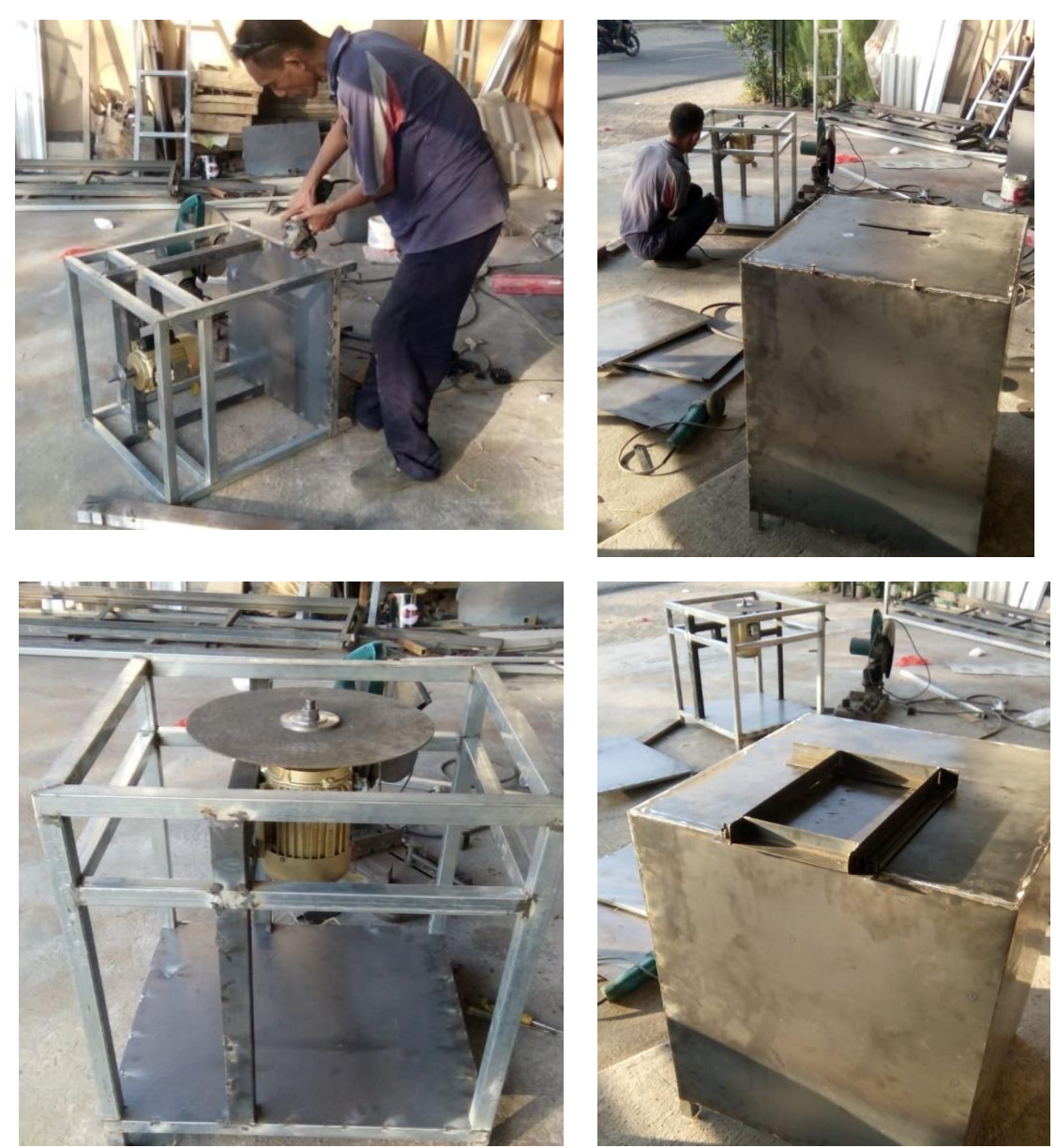

Gambar 5. Proses pembuatan alat TTG. 
(2) Pelatihan penggunaan alat TTG

Pada tahap ini dilakukan pelatihan penggunaan TTG dari tim pelaksana pengabdian masyarakat kepada UKM yang terdiri dari pemilik UKM dan tenaga kerjanya. Pelatihan ini dimaksudkan untuk mengenalkan pemanfaatan TTG dalam menunjang produktifitas UKM, dijelaskan proses kerja alat dan penggunaanya.
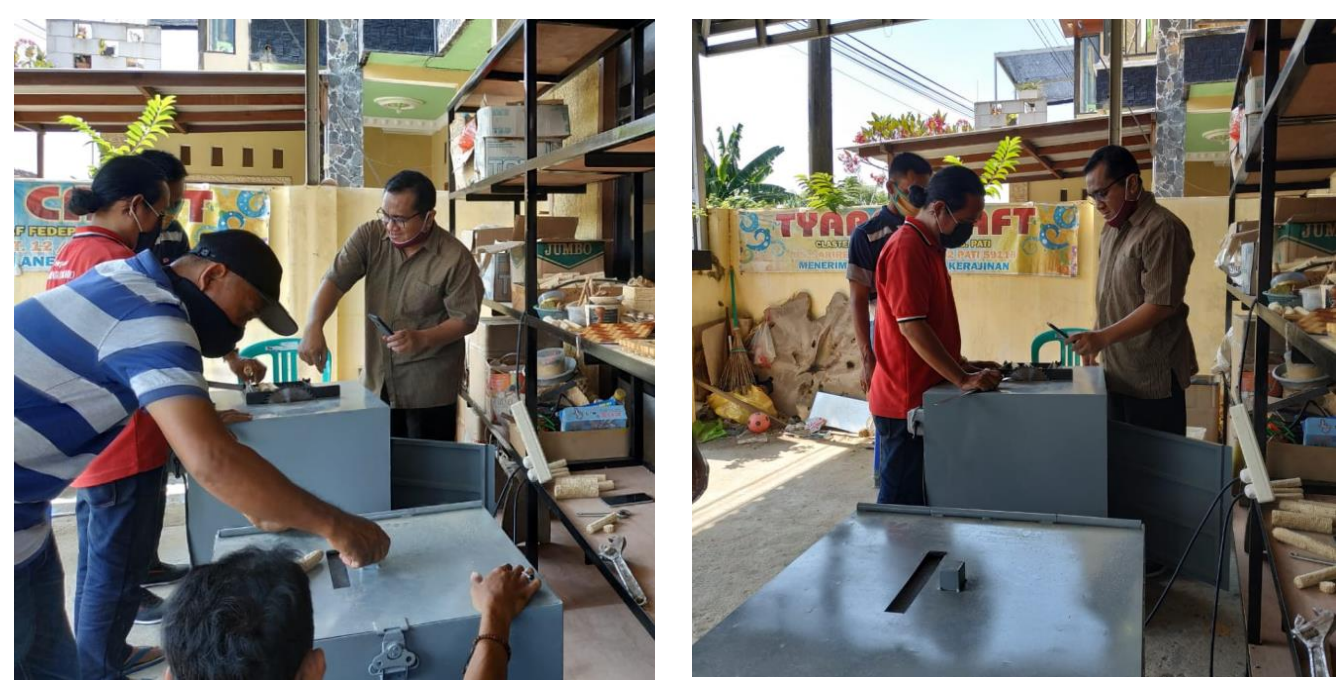

Gambar 6. Pelatihan penggunaan alat TTG.

Prinsip kerja mesin pemotong adalah bonggol yang sudah diamplas dipotong dengan gergaji/sirkel dengan ukuran yang bisa diatur dengan pengaturan yang ada disebelah gergaji, dengan lubang yang ada disamping gergaji maka bonggol jagung yang sudah terpotong jatuh melalui lubang yang sudah dibatasi sehingga masuk kedalam wadah yang sudah disediakan di bawahnya. Sedangkan prinsip kerja mesin pengamplas adalah bonggol jagung yang sudah kering dimasukan ke lubang amplas sambil diputar dengan telapak tangan sehingga serabut bekas menempelnya bulirbulir jagung hilang dan menjadi halus, dengan rongga antara amplas dan permukaan/meja didorong angin perputaran amplas maka serabut bekas amplasan masuk ke cerobong bawah dan masuk ke tempat penampungan.

(3) Workshop peningkatan keahlian tenaga kerja dalam pemanfaatan TTG

Kegiatan workshop ini dimaksudkan untuk meningkatkan keahlian dari UKM dengan mengambil narasumber dari UKM kerajinan sejenis daro Yogya yang berpengalaman sudah memanfaatkan TTG dalam menunjang produksinya. Kegiatan worshop ini dilaksanakan melalui internet dengan webinar karena saat pelaksanaan masih masa pandemi Covid-19. Dari webinar ini, narasumber memberikan arahan sekaligus praktek penggunaan alat TTG supaya bisa menghasilkan produk yang bagus dengan waktu yang lebih efektif. 


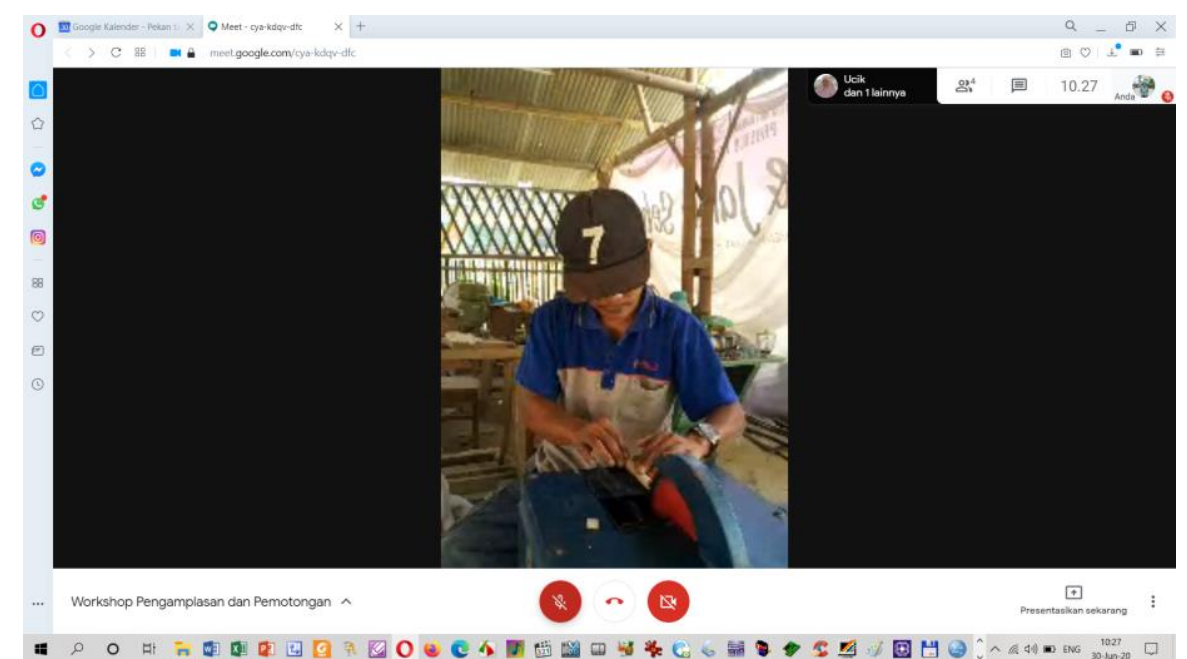

Gambar 7. Narasumber sedang memberi arahan cara pemotongan yang baik.

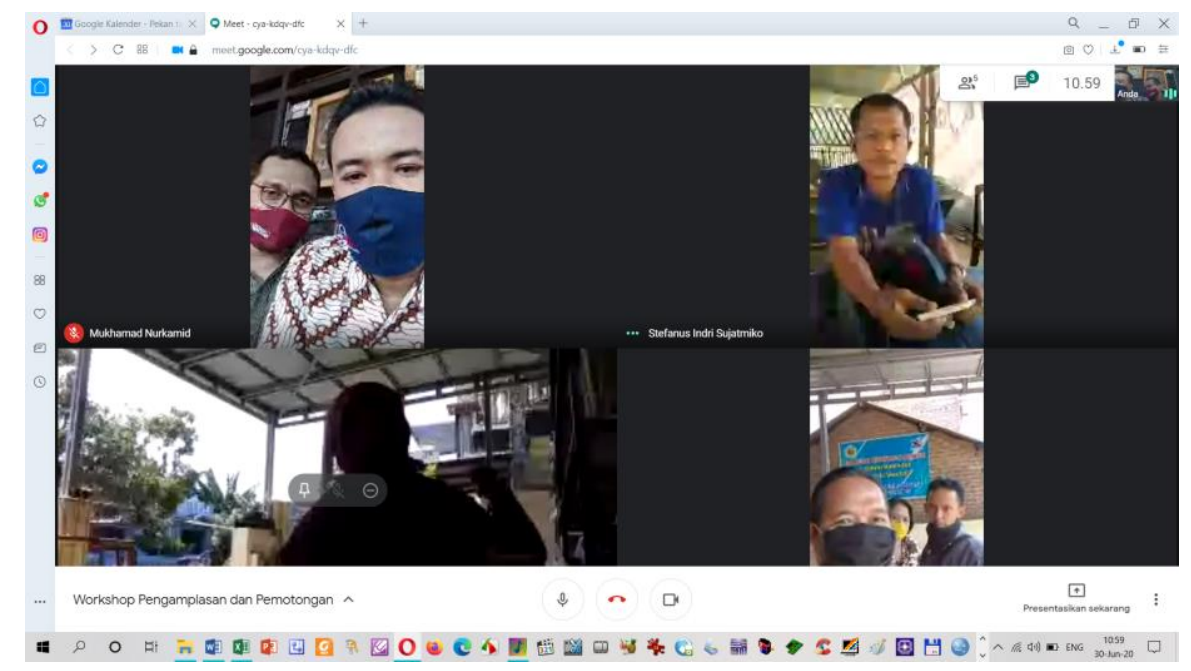

Gambar 8. Tim pelaksana, UKM dan narasumber sedang berkomunikasi melalui webinar.

\section{SIMPULAN}

Sesuai dengan Permendagri 20/2010 tentang Pemberdayaan Masyarakat Melalui Pengelolaan Teknologi Tepat Guna, saat ini peranan teknologi memang sangat penting untuk mendongkrak kinerja UKM dan mengatasi kesulitan yang sering mereka hadapi khususnya dalam hal memproduksi barang komoditas yang berkualitas. Melalui sentuhan teknologi dan didukung dengan SDM yang handal, diharapkan kualitas produk yang dihasilkan pelaku UKM bisa terjaga kualitasnya, sehingga bisa bersaing dengan produk luar negeri dan untung yang dihasilkan bisa semakin besar.
Dengan memanfaatkan teknologi tepat guna, diharapkan seluruh UKM di Indonesia bisa memenuhi standar mutu produk yang berkualitas, menurunkan biaya produksinya, serta menghasilkan harga jual yang bersaing dan mendapatkan keuntungan yang lebih baik dengan efisiensi waktu dan tenaga yang di curahkan dalam proses roduksi.

Dari hasil evaluasi pelaksanaan pengabdian pada masyarakat dengan penerapan TTG di UKM ini, hasil yang didapat oleh UKM diantaranya adalah; (1) peningkatan produktifitas UKM , (2) peningkatan keahlian UKM, 
peningkatan omset penjualan dengan meningkatnya volume produksi.

\section{UCAPAN TERIMAKASIH}

Ucapan terima kasih disampaikan kepada Kementerian Riset dan Teknologi/Badan Riset dan Inovasi Nasional Deputi Bidang Penguatan Riset

\section{DAFTAR PUSTAKA}

Bappenas, 2006, Panduan Pembangunan Industri: Untuk Pengembangan Ekonomi Daerah Berdaya Saing Tinggi, Direktorat Pengembangan Kawasan Khusus dan Tertinggal, Bappenas, Jakar ta.

Desrochers dan Sautet. 2004. Cluster Based Economic Strategy, Fasilitation Policy and The Market Process, The Review og Austrian Economics, Vol. 17. P. 233 -245 .

Hill, H., 2001, Small and Medium Enterprises In Indonesia: Old Policy Challenges for a New Administration. Asian Survey, 41(2): 248-70. Isard, Walter, 1956, Location and Space Economy. Cambridge: MIT Press.

Kurniawan, A., Pengelolaan Teknologi Tepat Guna bagi UKM, http://neraca.co.id, diakses pada $10 \mathrm{Juli}$ 2020

Kuncoro, M., 2002, Analisis Spasial dan Regional: Studi Aglomerasi dan Kluster Industri Indonesia. Yogyakarta: UPP-AMP YKPN.

Rosenfeld. 1995. Labour Market Implication of Scale, Innovation, and Entrepreneurship. Washington DC. US Commision on Immigration Reform's dan Pengembangan yang telah mendanai kegiatan pengabdian pada masyarakat ini melalui hibah PPPUD tahun 2020.

Maxico-US Binational Migration Study.

Polnaya, G.A. and Darwanto, D., 2015. Strategi Pengembangan Ekonomi Lokal Untuk Meningkatkan Daya Saing Pada UKM Ekonomi Kreatif Batik Bakaran Di Pati, Jawa Tengah. Fakultas Ekonomika dan Bisnis

Purnomo, R.A., Ekonomi Kreatif "Pilar Pembangunan Indonesia" diterbitkan secara mandiri dalam situs http://nulisbuku.com, diakses pada 3 September 2019.

Ramdani, Nurhakim, "Peran Ekonomi Kreatif Dalam Tantangan ASEAN Economic Cummunity 2015”, http://nurhakimramdani.blogspot.co.id , diakses pada 3 September 2019

Peraturan Daerah Kabupaten Pati Nomor 1 Tahun 2018 tentang Rencana Pembangunan Jangka Menengah daerah Kabupaten Pati Tahun 2017 2022.

Repositori USU, 2015, "Kondisi UMKM Indonesia dalam Implementasi Masyarakat Ekonomi ASEAN", http://repository.usu.ac.id, diakses tanggal 3 September 2019 
Tambunan, T., 1999, Perkembangan

Industri Skala Kecil Di Indonesia.

Jakarta: PT. Mutiara Sumber Widya 